\title{
Introducción a la Política
}

\author{
FERNANDO MIRES
}

\section{LOM Ediciones. Santiago de Chile, 2004, 262 págs.}

Este libro se fundamenta en la siguiente tesis: la política como práctica e ideal, es una noción relacionable, lo que significa que su realidad no se explica en sí o de por sí mismo, sino en vinculación con otra u otras realidades.

El autor divide su exposición en quince capítulos en que relaciona a la noción de la política con un espacio de realidad no político. De esta manera se ha vinculado a la política con "complementos" como el estado, el poder, la guerra, el pueblo, la historia, la economía, el progreso, la burocracia, la barbarie, la moral, el antagonismo, la responsabilidad, la ideología, la mentira y la verdad.

La estrategia declarada del texto consiste en establecer hitos que posibiliten sistematizar semejanzas y diferencias desde las cuales sea factible ir perfilando la identidad de lo que es política y de lo que es político, de modo que el lector pueda ir añadiendo y completando una identificación más precisa de un tema siempre inconcluso.

La argumentación que se adopta deriva del pensamiento de un conjunto de filósofos de distintas épocas. Es así como arranca desde Aristóteles, Hobbes, Machiavelo y Kant, hasta culminar con filósofos políticos de la modernidad como Max Weber, Hannah Arendt y Carl Schmitt.

Justifica el autor la línea escogida por ser más potente y adecuada para analizar la política de nuestros días, en tanto la concibe como un ámbito indeterminado de acción imposible de ser construido antes que el hecho político acontezca. Por lo mismo, permite la posibilidad de lo contingente que siempre abre nuevos procesos y alternativas tendientes a desencadenar otras acciones políticas.

De ahí que descarte otras opciones posibles como la que empieza con Platón y continua en los tiempos modernos con Rousseau, Marx, Hegel y Gramci, para quienes el hecho político aparece como resultado del juego dialéctico, de modo que la dialéctica explicativa precede al hecho que se desea explicar. 
De acuerdo a las palabras de Mires, el mundo no es dialéctico en sí. Es sólo dialéctico si lo pensamos de modo dialéctico.

El libro no sigue necesariamente una exposición lineal. Cada capítulo remite a la polis griega y a la virtud que es la esencia misma de la condición política, según Aristóteles, y la política como profesión en Weber, quien la concibe intrínsecamente asociada con la idea de poder - sin poder no hay política - y con la responsable administración del Estado.

Para Arendt y Schmitt, en cambio, lo político se desarrolla en espacios que son construidos por antagonismos que se forman durante la lucha por el poder, tanto dentro como fuera del Estado. Ambos autores postulan que el poder político existe en cuanto haya lucha por alcanzarlo, por ello se requiere que nadie sea un ocupante definitivo de los espacios de poder.

Sobre la base de lo anterior, mediante una continua reflexión y "conversación" con los filósofos, el libro va proporcionando pistas orientadoras a los procesos democratizadores, en particular de aquellos que tienen lugar en América Latina. Advierte sobre los peligros de la relación perversa entre los negocios y la política, la tendencia a la manipulación mediática de los ciudadanos, las amenazas que conllevan los populismos, la demagogia y, especialmente, el totalitarismo y las dictaduras.

En una época en que los políticos "gozan" de un severo desprestigio en la opinión pública latinoamericana, resulta muy valioso emprender con el autor una revisión crítica del sentido de la política que, de acuerdo a la sentencia de Hannah Arendt que precede a la presentación del texto, no es otro que la libertad. 